Egyptian Journal of Aquatic Biology \& Fisheries

Zoology Department, Faculty of Science,

Ain Shams University, Cairo, Egypt.

ISSN $1110-6131$

Vol. 24(7): $817-823$ (2020)

www.ejabf.journals.ekb.eg

\title{
Biochemical composition and caloric values of different body segments of the female mangrove crab (Scylla olivacea)
}

\author{
Md. Akram Ullah ${ }^{1}$, Mohammad Iqbal Hossain ${ }^{1}$, Towhid Hasan ${ }^{2}$, Marjia Sultana ${ }^{2}$, Md. \\ Nurul Huda Babu ${ }^{1}$ and Md. Robiul Hasan ${ }^{1}$ \\ ${ }^{1}$ Department of Fisheries and Marine Science, Noakhali Science and Technology University, \\ Noakhali-3814, Bangladesh \\ ${ }^{2}$ Department of Food Technology and Nutrition Science, Noakhali Science and Technology \\ University, Noakhali-3814, Bangladesh
}

*Corresponding Author: akramnstu@gmail.com

\section{ARTICLE INFO}

Article History:

Received: Sept. 30, 2020

Accepted: Nov. 29, 2020

Online: Dec. 12, 2020

\section{Keywords:}

Mangrove Crab,

Biochemical

Composition,

Nutritional profile.

\begin{abstract}
Scylla olivacea is regarded as a nutritionally and economically demandable species, however, there lies a paucity of information on this mangrove crab. Therefore, the objective of the present study is to assess the biochemical composition and caloric values of different body parts of female S. olivacea. The crab samples (100-150g) were collected from a mangrove area of Bagerhat district, the Southern part of Bangladesh from November 2019 to February 2020. The biochemical composition (moisture, protein, lipids, ash, and carbohydrate) and the energy value of the samples were analyzed following standardized methods. The moisture content varied from $38.99 \pm 1.29 \mathrm{~g}$ to $75.15 \pm 0.78 \mathrm{~g}$ per $100 \mathrm{~g}$ of crab. The carbohydrate level was in the range of $2.89 \mathrm{~g} / 100 \mathrm{~g}$ to $27.77 \mathrm{~g} / 100 \mathrm{~g}$, while protein content ranging from $0.65 \pm 0.10 \mathrm{~g} / 100 \mathrm{~g}$ to $19.24 \pm 0.90 \mathrm{~g} / 100 \mathrm{~g}$. Per $100 \mathrm{~g}$ of crab, the lowest amount of fat $(0.40 \pm 0.14 \mathrm{~g})$ was observed in the bone while the highest amount $(1.79 \pm 0.17 \mathrm{~g})$ in claw meat. Bone provided the highest amount of ash $(32.20 \pm 0.69 \mathrm{~g} / 100 \mathrm{~g})$ and energy $(117.34 \mathrm{kcal} / 100 \mathrm{~g})$ than other body parts of the crab. The present study reveals that female S. olivacea is high in protein and low in fat providing a good amount of energy. Hence, research on S. olivacea and other crabs commonly found in Bangladesh should be expanded to get more comprehensive knowledge of their nutritional profile and health benefits.
\end{abstract}

\section{INTRODUCTION}

Crab is considered as a vital member of decapod crustaceans belonging to the shellfish group and living in marine, brackish, or freshwaters habitat. Crabs can be extensively found in shallow waters, especially in mangrove areas and estuaries (Wan Yusof et al., 2019). In Bangladesh, crabs particularly dwell in the estuaries, tidal rivers of the Sundarbans shrimp polders (Khan and Alam, 1992). Crabs are good exportable fishery 
products and hidden valuable resources in Bangladesh (Ahmed, 1992). Nowadays it's become a popular fisheries item and a typical seafood product among other seafood in Bangladesh.

A total of Sixteen crab species has been reported from Bangladesh including Scylla serrata, Scylla olivacea, Portunas pelagicus, P. sanguinolentus, Charybdis feriata, Charybdis rostrata, Matuta lunaris, M. planipes, Clappa lophos, C. pustulosa, Varuna litterata, Sartorina spinigera, Ocypoda cratopthalma, and Gelasimus annulipes (Banglapedia, 2014). Studies found that crab is a good source of nutrition and a valuable fishery product, particularly for the two species known as $S$. serrata and $S$. paramamosain (Keenan et al., 1998, Zafar et al., 2004, Meng et al., 2017)

S. olivacea is known as mangrove crab or olive crab, which is available in the mangrove area and seasonally in the coastal region. S. olivacea is considered to be nutritionally and economically demandable species, thus coastal people are more encouraged to culture this species commercially. Studies found that the biological properties of mangrove crabs consist of antimicrobial peptides and antioxidants that can be directly applied to the food, agriculture, and pharmaceutical industries (Sperstad et al., 2011, Zhao et al., 2015, Wan Yusof et al., 2017). Consequently, biochemical composition among the different body segment of $S$. olivacea is necessary.

While the comparative study on the biochemical composition of other crabs (e.g., mud crab $S$. serrata) is available in the literature, there is little information found about $S$. olivacea. Therefore, we attempted to assess nutritional value in different body segments of mangrove crab, S. olivacea. We assume our study would be helpful for better understanding the nutritional value of these particular crab body meat and to compare the nutritional values of similar food and food products.

\section{MATERIALS AND METHODS}

\section{Study area and sampling}

The samples (7-10 crabs, 100-150g each) were collected from 7 different locations of mangrove area in Bagerhat district, the Southern part of Bangladesh from November 2019 to February 2020, as shown in Figure 1.

Immediately after collection, the crabs were stored in an icebox and carried it to the laboratory of Glove Agrovet Limited, Mirwarishpur, Noakhali. Mud crabs were washed carefully with tap water. Then a dissection box and some other equipment were used to collect crab meat. The crab meat was collected from different segments of their body and kept it in a different tray. About 50-100g of crab meat was taken from each of the 7 locations and mixed together to prepare a composite homogenous mixture. At the end, these composite samples were used for biochemical analysis. 


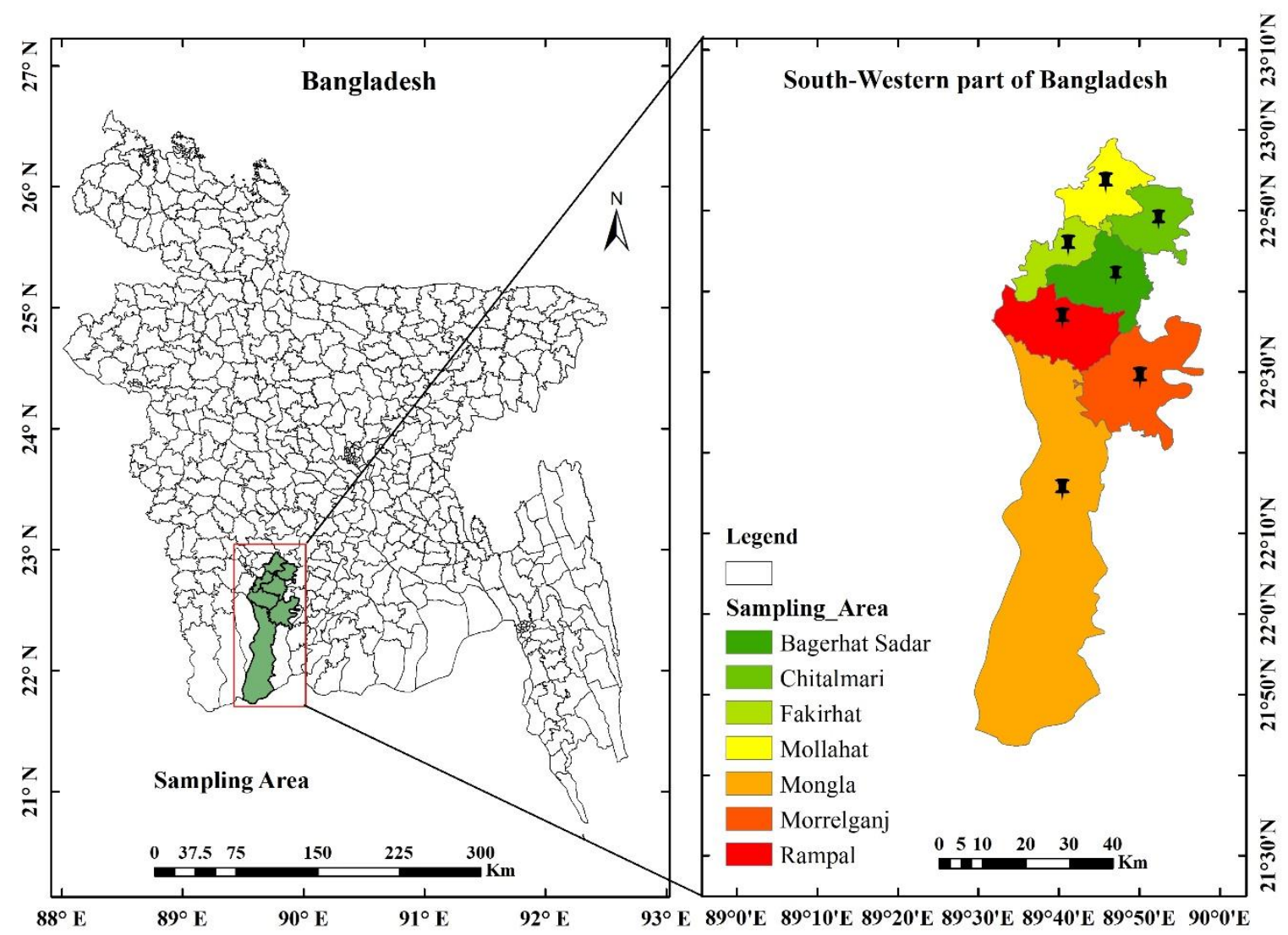

Figure 1. Location of the study area along with the sampling sites.

\section{Determination of biochemical composition}

\section{Moisture content}

The amount of moisture in different body segments of $S$. olivacea was determined by the AOAC method (AOAC, 1990).

\section{Total ash}

Total ash content was estimated following the AOAC method (AOAC, 1990).

\section{Crude protein}

The amount of crude protein was assessed by the Kjeldahl method (Bradstreet, 1965).

\section{Total lipid}

Lipid content was estimated by Soxhlet's method (Pearson, 1976).

\section{Total carbohydrate}

The total carbohydrate content was calculated by difference.

\section{Energy content}

The energy content of different body parts of mangrove crab was determined using factors 4,4 , and 9 for carbohydrates, protein, and fat, respectively.

\section{Statistical analysis}

All analyses were carried out in triplicate. The Statistical Package for the Social Sciences (SPSS) software (version 26.0) for Windows (SPSS, Inc., Chicago, IL, USA) was used for data analyses. The results were presented as mean and standard deviation (SD). 
Moreover, the differences in the mean of moisture, carbohydrate, protein, fat, and ash content, and energy level between different body parts of $S$. olivacea were compared using one-way analysis of variance (ANOVA) test. A P value of less than 0.05 was considered statistically significant for all tests.

\section{RESULTS AND DISCUSSION}

Biochemical analysis is imperative to generate knowledge on nutritional and biochemical composition and specific nutritional information like protein, fat, carbohydrate, and mineral content of mud crabs commonly found in Bangladesh is not well documented. In the present study, we conducted a biochemical analysis of mangrove crab S. olivacea. Table 1 shows the biochemical compositions of different body segments of female $S$. olivacea.

Table 1. Biochemical composition $(\mathrm{g} / 100 \mathrm{~g})$ of different body segments of female Scylla olivacea.

\begin{tabular}{llllll}
\hline & Moisture & Carbohydrate & Protein & Fat & Ash \\
\hline Claw meat & $75.15 \pm 0.78^{\mathrm{a}}$ & $2.96 \pm 0.54^{\mathrm{a}}$ & $18.86 \pm 0.76^{\mathrm{a}}$ & $1.79 \pm 0.17^{\mathrm{c}}$ & $1.24 \pm 0.12^{\mathrm{a}}$ \\
Breast meat & $74.94 \pm 1.14^{\mathrm{a}}$ & $2.89 \pm 0.40^{\mathrm{a}}$ & $19.24 \pm 0.90^{\mathrm{a}}$ & $1.46 \pm 0.09^{\mathrm{a}}$ & $1.46 \pm 0.20^{\mathrm{a}}$ \\
Bone & $38.99 \pm 1.29^{\mathrm{b}}$ & $27.77 \pm 1.39^{\mathrm{b}}$ & $0.65 \pm 0.10^{\mathrm{b}}$ & $0.40 \pm 0.14^{\mathrm{b}}$ & $32.20 \pm 0.69^{\mathrm{b}}$ \\
Whole body & $74.96 \pm 1.00^{\mathrm{a}}$ & $3.30 \pm 0.62^{\mathrm{a}}$ & $19.10 \pm 0.43^{\mathrm{a}}$ & $1.43 \pm 0.07^{\mathrm{a}}$ & $1.20 \pm 0.08^{\mathrm{a}}$ \\
\hline
\end{tabular}

Data are mean \pm standard deviation. Values within the same column with different letters are significantly different $(\mathrm{P}<0.05)$.

The water content ranged from $38.99 \pm 1.29 \mathrm{~g}$ in the bone to $75.15 \pm 0.78 \mathrm{~g}$ in claw meat with $74.96 \pm 1.00 \mathrm{~g}$ in whole-body per $100 \mathrm{~g}$ of female crab. This finding is not consistent with the previously reported moisture content of S. olivacea (Lyla et al., 2017, Wan Yusof et al., 2019). Some previous studies on S. serrata and S. tranquebarica found similar moisture levels with the present study (George and Gopakumar, 1987, Zafar et al., 2004, Paul et al., 2015, Sreelakshmi et al., 2016).

The carbohydrate level of female mangrove crab was the lowest in breast meat $(2.89 \mathrm{~g} / 100 \mathrm{~g})$ and the highest in bone $(27.77 \mathrm{~g} / 100 \mathrm{~g})$ where the whole-body carbohydrate content was $3.30 \pm 0.62 \mathrm{~g} / 100 \mathrm{~g}$. A previous study on $S$. olivacea showed similar carbohydrate content (Wan Yusof et al., 2019), however, the present finding is higher than another study on S. olivacea (Lyla et al., 2017). Some studies on S. serrata also showed lower carbohydrate content than the present study (Zafar et al., 2004, Vijaya Bharathi et al., 2018).

All of the body parts of female $S$. olivacea contained a similar amount of protein as whole-body $(19.10 \pm 0.43 \mathrm{~g} / 100 \mathrm{~g})$ except bone $(0.65 \pm 0.10 \mathrm{~g} / 100 \mathrm{~g})$. The present findings corroborate those of other studies on S. olivacea and S. serrata (George and Gopakumar, 1987, Zafar et al., 2004, Wan Yusof et al., 2019). However, inconsistency in protein content was also observed with other studies on mud crabs (Sarower et al., 2013, Sreelakshmi et al., 2016, Lyla et al., 2017, Vijaya Bharathi et al., 2018)

The fat content varied within different body parts of the female crab i.e. the lowest amount observed in bone $(0.40 \mathrm{~g} / 100 \mathrm{~g})$ while claw meat had the highest amount $(1.79 \mathrm{~g} / 100 \mathrm{~g})$ and whole-body fat content was $1.43 \mathrm{~g} / 100 \mathrm{~g}$. This finding is in line with the lipid content of S. serrata and S. tranquebarica (George and Gopakumar, 1987, Sreelakshmi et al., 2016). However, it is different in compared to other studies on $S$. 
olivacea and other mud crabs (Zafar et al., 2004, Sarower et al., 2013, Paul et al., 2015, Lyla et al., 2017, Vijaya Bharathi et al., 2018, Wan Yusof et al., 2019)

Ash content was higher in bone $(32.20 \pm 0.69 \mathrm{~g} / 100 \mathrm{~g})$ than other body segments with whole-body ash content was $1.20 \pm 0.08 \mathrm{~g} / 100 \mathrm{~g}$ in female crab. The ash content noted in the present study is comparable to previous findings on mud crabs (Zafar et al., 2004, Sarower et al., 2013), although some noted different results (George and Gopakumar, 1987, Paul et al., 2015, Sreelakshmi et al., 2016, Lyla et al., 2017).

Figure 2 shows the energy content of different body parts of female S. olivacea. Bone provided the highest energy $(117.34 \mathrm{kcal} / 100 \mathrm{~g})$ and the whole-body energy level was $102.5 \mathrm{kcal} / 100 \mathrm{~g}$ of female mangrove crab.

140

b

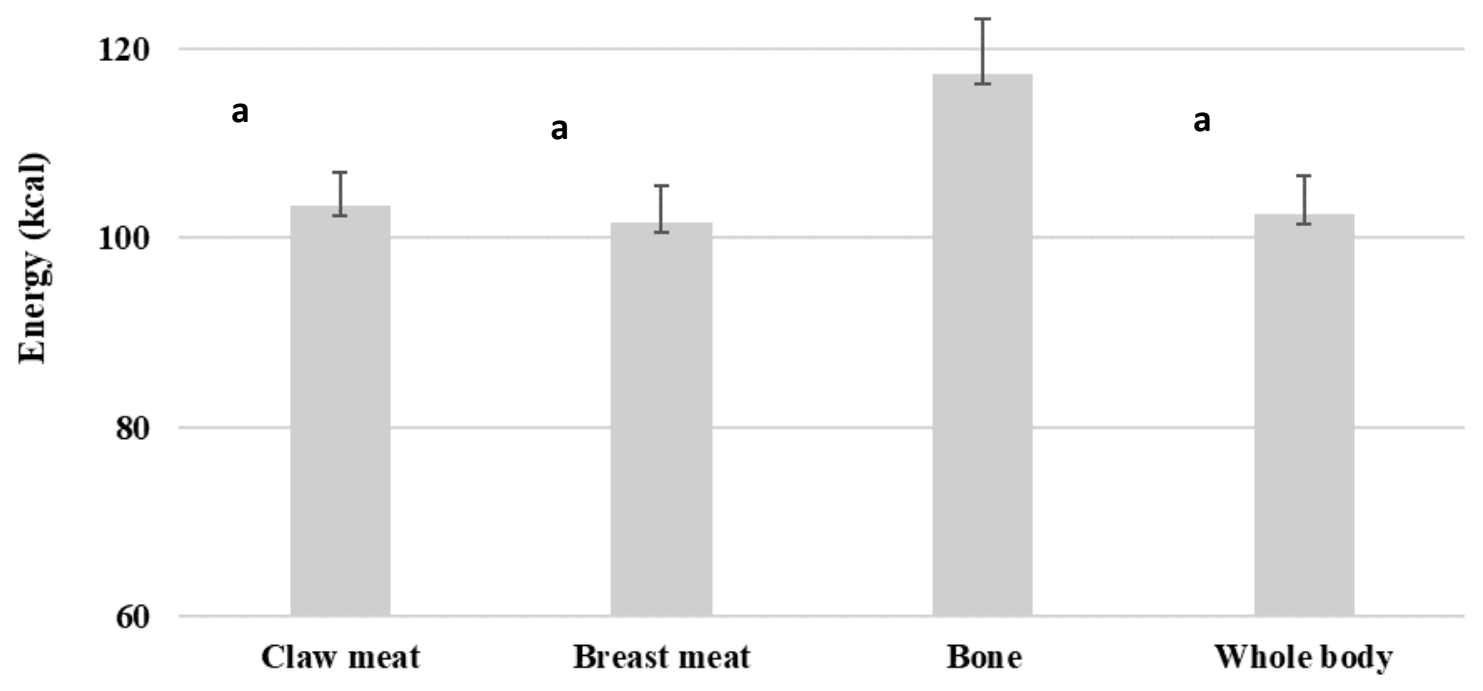

Figure 2. Mean $( \pm \mathrm{SD})$ energy content $(\mathrm{kcal} / \mathbf{1 0 0 g})$ of different body segments of female Scylla olivacea. Values within the same column with different letters are significantly different $(\mathrm{P}<0.05)$

The present study has some limitations. First, we conducted a biochemical analysis of female $S$. olivacea only. Analysis of both male and female crabs could provide gender differences in biochemical profiles. Second, the assessment of seasonal variation in biochemical composition could not be performed. Third, information like maturity, feeding practice, etc. were not collected which might affect the biochemical composition of crabs.

\section{CONCLUSION}

Crab is a good exportable fisheries product and a source of income for many people in Bangladesh. The results of the present study show that female S. olivacea is rich in protein and low in fat with a good source of energy, therefore, it can be a healthy choice for human consumption. It is thus recommended to enhance research on S. olivacea and 
other crabs commonly found in Bangladesh to have a more comprehensive knowledge of their nutritional profile and health benefits.

\section{ACKNOWLEDGEMENT}

We thank Glove Agrovet Ltd., Noakhali, Bangladesh for providing sufficient laboratory facilities.

\section{REFERENCES}

Ahmed, M.K. (1992). Mud crab - A potential aqua-resource of Bangladesh. In: Angell, C. A. (ed.) The Mud crab, a report on the Seminar convened in Surat, Thailand, November 5-8,1991. BOBP, Madras, India.

AOAC (1990). Official method of analysis, Association of Official Analytical Chemist, Washington DC.

Banglapedia (2014). Crab [Online]. National Encyclopedia of Bangladesh, Asiatic Society ofBangladesh,available at: http://en.banglapedia.org/index.php?title=Crab (accessed 15 July 2020)

Bradstreet, R.B. (1965). The Kjeldahl Method for Organic Nitrogen, Academic Press, USA.

George, C. and Gopakumar, K. (1987). Biochemical studies on crab Scylla serrata. Fishery Technol, Vol. 24 No. 1, pp. 57-61.

Keenan, C. P.; Davie, P.J.F. and Mann, D. L. (1998). A revision of the genus Scylla de Haan, 1833 (Crustacea: Decapoda: Brachyura: portunidae). Raffles Bull Zool, Vol. 46, pp. 217-245.

Khan, M. G. and Alam, M.F. (1992). The mud crab (Scylla serrata) fishery and its bioeconomics in Bangladesh. In: Angell, C. A. (ed.) The Mud crab, a report on the Seminar convened in Surat, Thailand, November 5-8,1991. BOBP, Madras, India.

Lyla, S.; Manikantan, G. and Khan, S.A. (2017). Proximate Composition of Edible and Potentially Useful Brachyuran Crabs of Parangipettai, Southeast Coast of India. Inventi Rapid Nutraceuticals, Vol. 2017 No. 1, pp. 1-5.

Meng, F.; Gao, H.; Tang, X.; Wang, A.; Yao, X.; Liu, C. and Gu, Z. (2017). Biochemical composition of pond-cultured vs. wild gravid female mud crab Scylla paramamosain in Hainan, China: evaluating the nutritional value of cultured mud crab, J Shellfish Res, Vol. 36 No. 2, pp. 445-452. 
Paul, B.; Faruque, M.H.; Mandal, R.N. and Ahsan, D.A. (2015). Nutritional susceptibility to morphological, chemical and microbial variability: an investigation on mud crab, Scylla serrata in Bangladesh. Int J Fish Aquat Stud, Vol. 2 No. 6, pp. 313-319.

Pearson, D. (1976). The Chemical analysis of foods, Longman Group Ltd, Harlow UK.

Sarower, M.; Bilkis, S.; Rauf, M.; Khanom, M. and Islam, M. (2013). Comparative biochemical composition of natural and fattened mud crab Scylla serrata. J Sci Res, Vol. 5 No. 3, pp. 545-553.

Sperstad, S.V.; Haug, T.; Blencke, H.M.; Styrvold, O.B.; Li, C. and Stensvåg, K. (2011). Antimicrobial peptides from marine invertebrates: challenges and perspectives in marine antimicrobial peptide discovery. Biotechnol Adv, Vol. 29 No. 5, pp. 519-530.

Sreelakshmi, K.; Manjusha, L.; Vartak, V. and Venkateshwarlu, G. (2016). Variation in proximate composition and fatty acid profiles of mud crab meat with regard to sex and body parts. Indian J Fish, Vol. 63 No. 2, pp. 147-150.

Vijaya Bharathi, T.; Chakravarty, M.S. and Ganesh, P. (2018). Biochemical composition of the of mud crab Scylla serrata (Forskal) of Coringa mangroves, Andhra Pradesh, India. Int J Adv Sci Res, Vol. 3 No. 1, pp. 11-15.

Wan Roslina; Yusof, W.R.; Ahmad, B.F.; Ahmad, N. M.; Husaini, A.S.A. and Swamy, M. (2019). Proximate Composition and Antioxidant Properties of Orange Mud Crab, Scylla olivacea. J Aquat Food Prod Technol, Vol. 28 No. 4, pp. 365-374.

Wan Roslina; Yusof, W.R.; Ahmad, B.F. and Swamy, M. (2017). A brief review on the antioxidants and antimicrobial peptides revealed in mud crabs from the genus of Scylla. J Mar Biol, Vol. 2017.

Zafar, M.; Siddiqui, M.Z.H. and Hoque, M.A. (2004). Biochemical composition in Scylla serrata (Forskal) of Chakaria Sundarbanarea, Bangladesh. Pak J Biol Sci, Vol. 7 No. 12, pp. 2182-2186.

Zhao, J.; Wen, X.; Li, S.; Zhu, D. and Li, Y. (2015). Effects of dietary lipid levels on growth, feed utilization, body composition and antioxidants of juvenile mud crab Scylla paramamosain (Estampador). Aquaculture, Vol. 435, pp. 200-206. 